\title{
Correction to: Lipopolysaccharides of Fusobacterium nucleatum and Porphyromonas gingivalis increase RANKL- expressing neutrophils in air pouches of mice
}

Ae Ri Kim ${ }^{1,2,3}$, Yun Kyong Lim ${ }^{4}$, Joong-Ki Kook ${ }^{4}$, Eun-Jung Bak ${ }^{1 *}$ and Yun-Jung Yoo ${ }^{*^{*}}$

Correction to: Lab Anim Res 37, 5 (2021)

https://doi.org/10.1186/s42826-020-00080-y

It was highlighted that in the original article [1] the superscript of the y-axis unit in the right panel of Fig. 3, panel a, was missing (10 should be $\left.10^{5}\right)$. This Correction article shows the correct Fig. 3. The original article has been updated.

\begin{abstract}
Author details
'Department of Oral Biology, College of Dentistry, Yonsei University, Seoul, Republic of Korea. ${ }^{2}$ Department of Applied Life Science, The Graduate School, Yonsei University, Seoul, Republic of Korea. ${ }^{3}$ BK21 PLUS Project, College of Dentistry, Yonsei University, Seoul, Republic of Korea. ${ }^{4}$ Korean Collection for Oral Microbiology and Department of Oral Biochemistry, School of Dentistry, Chosun University, Gwangju, Republic of Korea.
\end{abstract}

Published online: 09 August 2021

\section{Reference}

1. Kim, et al. Lipopolysaccharides of Fusobacterium nucleatum and

Porphyromonas gingivalis increase RANKL-expressing neutrophils in air pouches of mice. Lab Anim Res. 2021;37:5. https://doi.org/10.1186/s42826020-00080-y.

The original article can be found online at https://doi.org/10.1186/s42826 020-00080-y.

* Correspondence: ejbak@yuhs.ac; yu618@yuhs.ac

'Department of Oral Biology, College of Dentistry, Yonsei University, Seoul, Republic of Korea

Full list of author information is available at the end of the article

(c) The Author(s). 2021 Open Access This article is licensed under a Creative Commons Attribution 4.0 International License, which permits use, sharing, adaptation, distribution and reproduction in any medium or format, as long as you give appropriate credit to the original author(s) and the source, provide a link to the Creative Commons licence, and indicate if changes were made. The images or other third party material in this article are included in the article's Creative Commons licence, unless indicated otherwise in a credit line to the material. If material is not included in the article's Creative Commons licence and your intended use is not permitted by statutory regulation or exceeds the permitted use, you will need to obtain permission directly from the copyright holder. To view a copy of this licence, visit http://creativecommons.org/licenses/by/4.0/. The Creative Commons Public Domain Dedication waiver (http://creativecommons.org/publicdomain/zero/1.0/) applies to the data made available in this article, unless otherwise stated in a credit line to the data. 


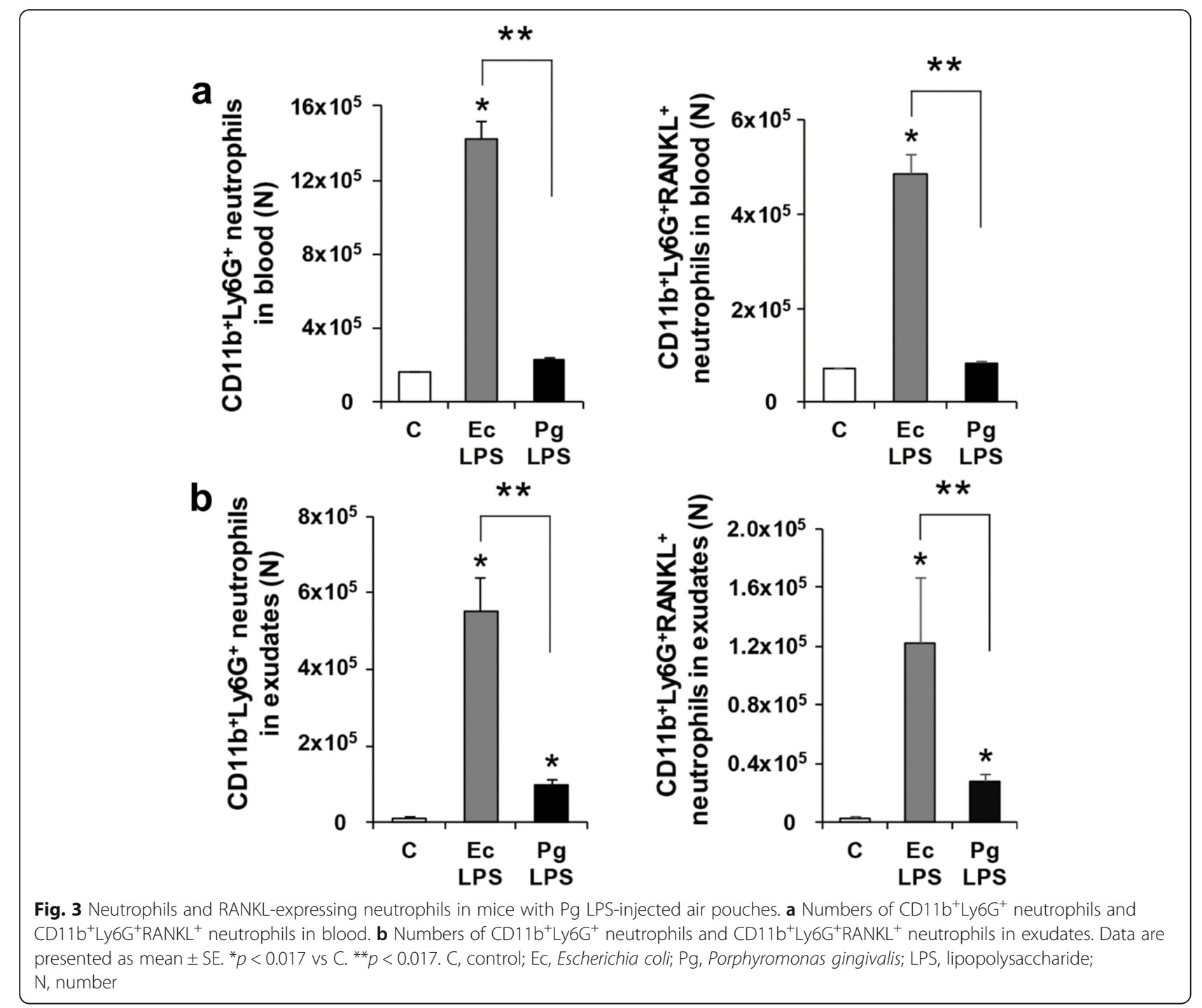

